\title{
NGL-2 Regulates Pathway-Specific Neurite Growth and Lamination, Synapse Formation, and Signal Transmission in the Retina
}

\author{
Florentina Soto, ${ }^{1}$ Kelly L. Watkins, ${ }^{1}$ Robert E. Johnson, ${ }^{1}$ Frank Schottler, ${ }^{1}$ and Daniel Kerschensteiner ${ }^{1,2,3}$ \\ Departments of ${ }^{1}$ Ophthalmology and Visual Sciences and ${ }^{2}$ Anatomy and Neurobiology, and ${ }^{3}$ Hope Center for Neurological Disorders, Washington \\ University School of Medicine, St. Louis, Missouri 63110
}

Parallel processing is an organizing principle of many neural circuits. In the retina, parallel neuronal pathways process signals from rod and cone photoreceptors and support vision over a wide range of light levels. Toward this end, rods and cones form triad synapses with dendrites of distinct bipolar cell types, and the axons or dendrites, respectively, of horizontal cells (HCs). The molecular cues that promote the formation of specific neuronal pathways remain largely unknown. Here, we discover that developing and mature HCs express the leucine-rich repeat (LRR)-containing protein netrin-G ligand 2 (NGL-2). NGL-2 localizes selectively to the tips of HC axons, which form reciprocal connections with rods. In mice with null mutations in $\mathrm{Ngl-2}\left(\mathrm{Ngl-} 2^{-/-}\right)$, many branches of $\mathrm{HC}$ axons fail to stratify in the outer plexiform layer (OPL) and invade the outer nuclear layer. In addition, HC axons expand lateral territories and increase coverage of the OPL, but establish fewer synapses with rods. NGL-2 can form transsynaptic adhesion complexes with netrin-G2, which we show to be expressed by photoreceptors. In $\mathrm{Ngl-2}-1-$ mice, we find specific defects in the assembly of presynaptic ribbons in rods, indicating that reverse signaling of complexes involving NGL-2 regulates presynaptic maturation. The development of HC dendrites and triad synapses of cone photoreceptors proceeds normally in the absence of NGL-2 and in vivo electrophysiology reveals selective defects in rod-mediated signal transmission in $\mathrm{Ngl-2}-1-$ mice. Thus, our results identify NGL-2 as a central component of pathway-specific development in the outer retina.

\section{Introduction}

Many circuits including those in the somatosensory, main and accessory olfactory, and visual systems contain parallel neuronal pathways that process distinct information (Wässle, 2004; Fox and Wong, 2005; Su et al., 2009; Meeks et al., 2010; Sanes and Zipursky, 2010). This organization requires developing neurons to target neurites, establish synaptic contacts, differentiate aligned presynaptic and postsynaptic specializations, and adjust

\footnotetext{
Received April 9, 2013; revised May 23, 2013; accepted June 11, 2013.

Author contributions: F. Soto and D.K. designed research; F. Soto, K.L.W., R.E.J., F. Schottler, and D.K. performed research; F. Soto, R.J., and D.K. analyzed data; F. Soto and D.K. wrote the paper.

This work was supported by R01 EY021855 (D.K.) and P30 EY002687 (Department of Ophthalmology and Visual Sciences at Washington University), as well as by grants from the Whitehall Foundation (D.K.), Edward Mallinckrodt Jr. Foundation (D.K.), Alfred P. Sloan Foundation (D.K.), and the Research to Prevent Blindness Foundation (Career Development Award to D.K. and unrestricted grant to the Department of Ophthalmology and Visual Sciences at Washington University). We thank Drs. F. M. Bareyre and M. Kerschensteiner, and A. Schmalz for AAV-CAG-CFP viruses. We are grateful to Dr. J. N. Kay for advice on in situ hybridization experiments. We thank Sue Penrose for expert technical assistance in implanting mouse embryos. We thank members of the Kerschensteiner laboratory for helpful discussions and comments on this manuscript. The mutant mouse strain used for this research project, B6;12955-Lrrc ${ }^{\text {tm ILex/Mmucd }(032442-U C D,)}$ was obtained from the Mutant Mouse Regional Resource Center (MMRRC), a NCRR-NIH funded strain repository, and was donated to the MMRRC by Lexicon Genetics Incorporated. The $2 \mathrm{H} 3$ neurofilament antibody developed by Drs. T. M. Jessell and J. Dodd, was obtained from the Developmental Studies Hybridoma Bank (NICHD and University of lowa, Department of Biology).

The authors declare no competing financial interests.

Correspondence should be addressed to either Florentina Soto or Daniel Kerschensteiner, Department of Ophthalmology and Visual Sciences, Washington University School of Medicine, St. Louis, M0 63110. E-mail: soto@@ision.wustl.edu or dkerschensteiner@wustl.edu.

DOI:10.1523/JNEUROSCI.1521-13.2013

Copyright $\odot 2013$ the authors $\quad 0270-6474 / 13 / 3311949-11 \$ 15.00 / 0$
}

signal transmission in a pathway-specific manner. Recent studies have identified central roles for cell adhesion molecules (CAMs) containing leucine-rich repeat (LRR) domains in many aspects of neural development (Shen and Scheiffele, 2010; Siddiqui and Craig, 2011; de Wit et al., 2011). However, few proteins that promote the formation of specific vertebrate neuronal pathways have so far been identified, and whether individual cues control isolated aspects of pathway-specific connectivity (e.g., neurite targeting, synaptogenesis) or coregulate several is not well understood (Williams et al., 2010).

At the first synapse of the visual system, signals from rod and cone photoreceptors (PRs), which operate at low and high luminance, respectively, enter parallel neuronal pathways (Masland, 2001; Wässle, 2004). PRs form triad synapses with horizontal cells (HCs) and bipolar cells (BCs) in the retina's outer plexiform layer (OPL). At triad synapses, presynaptic ribbons anchored near the apex of invaginations in rod spherules and cone pedicles mediate glutamate release (Matthews and Fuchs, 2010; Regus-Leidig and Brandstatter, 2012). Distinct BC types send dendrites into rod (rod BCs, RBCs) and cone (cone BCs, CBCs) invaginations and relay $\mathrm{PR}$ signals to separate targets in the inner retina (Wässle et al., 2009). In addition, type B HCs - the only HC type in mice (Peichl and González-Soriano, 1994)_participate in triad synapses in a pathway-specific manner: their axons invade rods and their dendrites cones (Kolb, 1970, 1974). Terminals of HC axons and dendrites receive input from PRs via AMPA-type glutamate receptors (Hack et al., 2001; Pan and Massey, 2007) and both 
neurites provide local feedback to PRs via mechanisms that are currently under debate (Kamermans et al., 2001; Hirasawa and Kaneko, 2003; Hirano et al., 2005; Jackman et al., 2011). The molecules that guide the development of pathway-specific connections and signal transmission in the OPL remain unknown.

Surveying the expression of candidate genes encoding LRRcontaining CAMs, we here discover that developing and mature HCs express NGL-2 localized selectively to the tips of their axons. Combining viral single cell labeling and immunohistochemistry, we find that $\mathrm{HC}$ axons in $\mathrm{Ngl}-2$ knock-out $\left(\mathrm{Ngl-} 2^{-/-}\right)$mice overshoot their laminar target (i.e., the OPL), expand lateral territories, and form fewer synapses with rod PRs. By contrast, the development of HC dendrites and connections with cones proceeds normally in the absence of NGL-2. Electron microscopy further reveals that the assembly of presynaptic ribbons in rods, but not cones, is disrupted in $\mathrm{Ngl-} 2^{-/-}$mice, and in vivo electrophysiology shows selective changes in rod-mediated signaling in the outer retina. Together, our results identify NGL-2 as a key regulator of pathway-specific connectivity at the first synapse of the visual system.

\section{Materials and Methods}

Animals. To determine the subcellular distribution of NGL-2 in horizontal cells (HCs), we crossed Cst-2A-Cre mice (Taniguchi et al., 2011) to a fluorescent reporter line (Ai9), in which the red fluorescent protein tdTomato is expressed from a ubiquitously active gene locus/promoter combination (Madisen et al., 2010). Before mating, both mouse lines had been crossed into a C57BL/J6 background for more than five generations. To probe the function of NGL-2 in retinal development, we compared mice lacking the coding exon of the $\mathrm{Ngl}-2$ gene, which is alternatively referred to as Leucine-rich repeat containing 4 (Lrrc4) in the literature, in a mixed B6/129S5 background ( $\mathrm{Ngl-2^{-1- }}$ mice; B6;129S5-Lrrc4 ${ }^{\text {tmlLex }}$ / Mmucd; Mutant Mouse Regional Resource Centers, University of California, Davis, Davis, CA) (Tang et al., 2010) to wild-type littermates (WT). Throughout this study postnatal day $0(\mathrm{P} 0)$ was defined as the day of birth and results from mice of both sexes were combined. All procedures were approved by the Animal Studies Committee of Washington University School of Medicine and complied with the National Institutes of Health Guide for the Care and Use of Laboratory Animals.

Intraocular virus injections. To label isolated retinal $\mathrm{HCs}$ in vivo, we injected adeno-associated virus serotype $1 / 2(\mathrm{AAV})$ particles carrying a vector expressing cyan fluorescent protein (CFP) from a ubiquitously active promoter (CAG) into the vitreous humor of newborn (P0-P2) mice. $A A V-C A G-C F P$ viruses were a generous gift from Drs. F. M. Bareyre and M. Kerschensteiner (Institute of Clinical Neuroimmunology, Ludwig-Maximilians Universität München, Munich, Germany) (Bareyre et al., 2011). Before injection, mice were placed on ice for $\sim 2$ $\mathrm{min}$. Anesthesia was confirmed by the absence of toe-pinch reflexes. An incision along the boundary of the prospective eyelids was made to expose the eyes, a small glass pipette advanced through the sclera and retina into the vitreous space and $150 \mathrm{nl}$ of virus (genomic titer: $4 \times 10^{11}$ genome copies $/ \mathrm{ml}$ ) delivered using a Drummond Nanoject 2 injector. Mice were allowed to recover on an infrared heating pad and subsequently returned to their mothers.

Tissue preparation. Mice were deeply anesthetized with $\mathrm{CO}_{2}$ and killed by cervical dislocation before enucleation. Corneas were then punctured with a 30-gauge needle and eyes transferred into a chamber with oxygenated mouse artificial CSF ( $\mathrm{mACSF}$ ) containing the following (in $\mathrm{mm}$ ): $119 \mathrm{NaCl}, 2.5 \mathrm{KCl}, 1 \mathrm{NaH}_{2} \mathrm{PO}_{4}, 2.5 \mathrm{CaCl}_{2}, 1.3 \mathrm{MgCl}_{2}, 20$ HEPES, and 11 glucose. The $\mathrm{pH}$ of the mACSF was adjusted to 7.37 using $\mathrm{NaOH}$. For immunohistochemistry and in situ hybridization, retinas were isolated and mounted flat on filter paper or left in the eyecup for 30 min fixation with $4 \%$ paraformaldehyde in $\mathrm{mACSF}$ followed by rinsing in PBS $(3 \times 20$ $\mathrm{min})$. For electron microscopy, eyecups were fixed for $5 \mathrm{~min}$ in $4 \%$ glutaraldehyde in $0.1 \mathrm{~m}$ sodium cacodylate ( $\mathrm{pH} 7.35$ ). Retinas were then isolated and fixed for another $2-3 \mathrm{~h}$ in $4 \%$ glutaraldehyde in $0.1 \mathrm{M}$ sodium cacodylate, before rinsing in $0.1 \mathrm{~m}$ sodium cacodylate $(3 \times 20 \mathrm{~min})$.

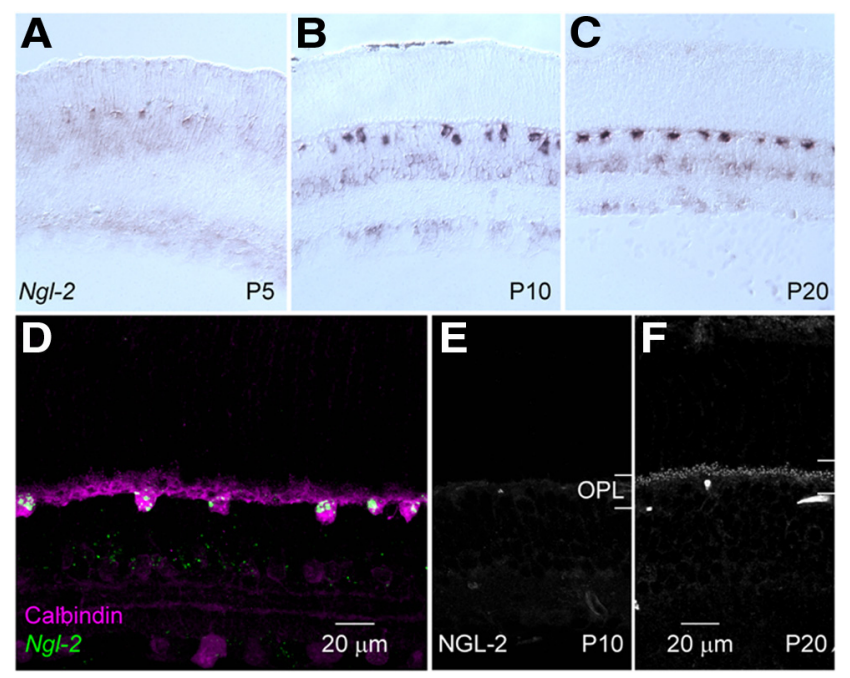

Figure 1. Expression patterns of $\mathrm{Ngl}-2$ mRNA and NGL-2 protein in the postnatal mouse retina. $\boldsymbol{A}-\boldsymbol{C}$, In situ hybridization of retinal cryostat sections showing the distribution and abundance of $\mathrm{Ngl}-2$ transcripts across different ages of development $(\boldsymbol{A}, \mathrm{P} 5 ; \boldsymbol{B}, \mathrm{P} 10 ; \boldsymbol{C}, \mathrm{P} 20)$. D, Combined fluorescent in situ hybridization for $\mathrm{Ngl}-2$ (green) and immunohistochemistry for the HC marker calbindin (magenta) in a P25 retina. $\boldsymbol{E}, \boldsymbol{F}$, Immunolabeling of NGL-2 in vibratome sections of P10 (E) and P20 (F) retinas. Lines bracket the OPL in $\boldsymbol{E}$ and $\boldsymbol{F}$.

In situ hybridization. In situ hybridization was performed following previously reported methods (Yamagata et al., 2002). DNA templates for riboprobes were prepared by PCR from IMAGE clones obtained from Open Biosystems (Ngl-2, EMM1002-97645303) or from retinal cDNA (Ntng2). Ntng2 cDNA was amplified using the following primers: forward, 5'-GCACTGCCTCCCGCTGGTCTCTG-3' and reverse, 5' GGGGCCCGTGGTGTTGTGTTCA-3'. Antisense RNA probes were synthesized using the DIG RNA labeling kit (Roche) from T7 sites incorporated by PCR in the DNA template. Tissue was prepared and fixed as for immunohistochemistry, cryoprotected, and sliced (thickness: $20 \mu \mathrm{m}$ ) using a cryotome (Leica). Slices were pretreated using proteinase K, postfixed, permeabilized using Triton X-100, and prehybridized for $4 \mathrm{~h}$ at $65^{\circ} \mathrm{C}$. Hybridization was performed overnight at $65^{\circ} \mathrm{C}$ using $1-2 \mu \mathrm{g} / \mathrm{ml}$ antisense RNA. The location of the hybridized riboprobe was detected using anti-DIG alkaline phosphatase labeled antibodies and BCIP/NBT overnight at room temperature (RT). For the combination of in situ hybridization and immunohistochemistry, the in situ signal was detected first using anti-DIG peroxidase-conjugated antibodies with Cy3-Tyramide as a substrate (PerkinElmer). Afterward, immunohistochemistry with an antibody against calbindin was performed (Kay et al., 2012).

Immunohistochemistry. Vibratome slices (thickness: $60 \mu \mathrm{m}$ ) or flat mount preparations were incubated with the following primary antibodies: mouse anti-NGL-2 (1:100, Neuromab), rabbit anti-calbindin (1: 1000 , Synaptic Systems), mouse anti-PKC $\alpha$ (1:1000, Sigma), guinea pig anti-VGluT1 (1:1000, Millipore), mouse anti-CACNA1S (1:1000, Millipore), mouse anti-Bassoon (1:500, Enzo), mouse anti-PKARII $\beta$ (1:500, BD Biosciences), mouse anti-GluR2 (1:200, BD PharMingen), mouse anti-neurofilament (1:2000, Developmental Studies Hybridoma Bank), mouse anti-G $\alpha$ o (1:2000, Millipore), mouse anti-DsRed (1:1000, Abcam), rabbit anti-cone arrestin (Millipore, 1:2000) for $1 \mathrm{~d}$ (vibratome slices) or $5 \mathrm{~d}$ (flat mounts) at $4^{\circ} \mathrm{C}$. Slices and flat mounts were then washed in PBS $(3 \times 30 \mathrm{~min})$, incubated with Alexa488-, Alexa568-, and Alexa633-conjugated secondary antibodies (1:1000, Invitrogen) for $2 \mathrm{~h}$ at $\mathrm{RT}$ (vibratome slices) or $1 \mathrm{~d}$ at $4^{\circ} \mathrm{C}$ (flat mounts), washed again in PBS $(3 \times 30 \mathrm{~min})$, and mounted for confocal imaging.

Confocal microscopy. Image stacks were acquired on an Fv1000 confocal laser-scanning microscope (Olympus) using a $60 \times 1.35$ NA oil-immersion objective at a voxel size of $0.103-0.3 \mu \mathrm{m}(x / y-z)$ or $0.206-0.3 \mu \mathrm{m}$. Image volumes were processed in Amira (Visage Imaging) and ImageJ/Fiji (http://rsbweb.nih.gov/ij), and analyzed using custom scripts written in Matlab (MathWorks) or R (http://www.r-project.org). 

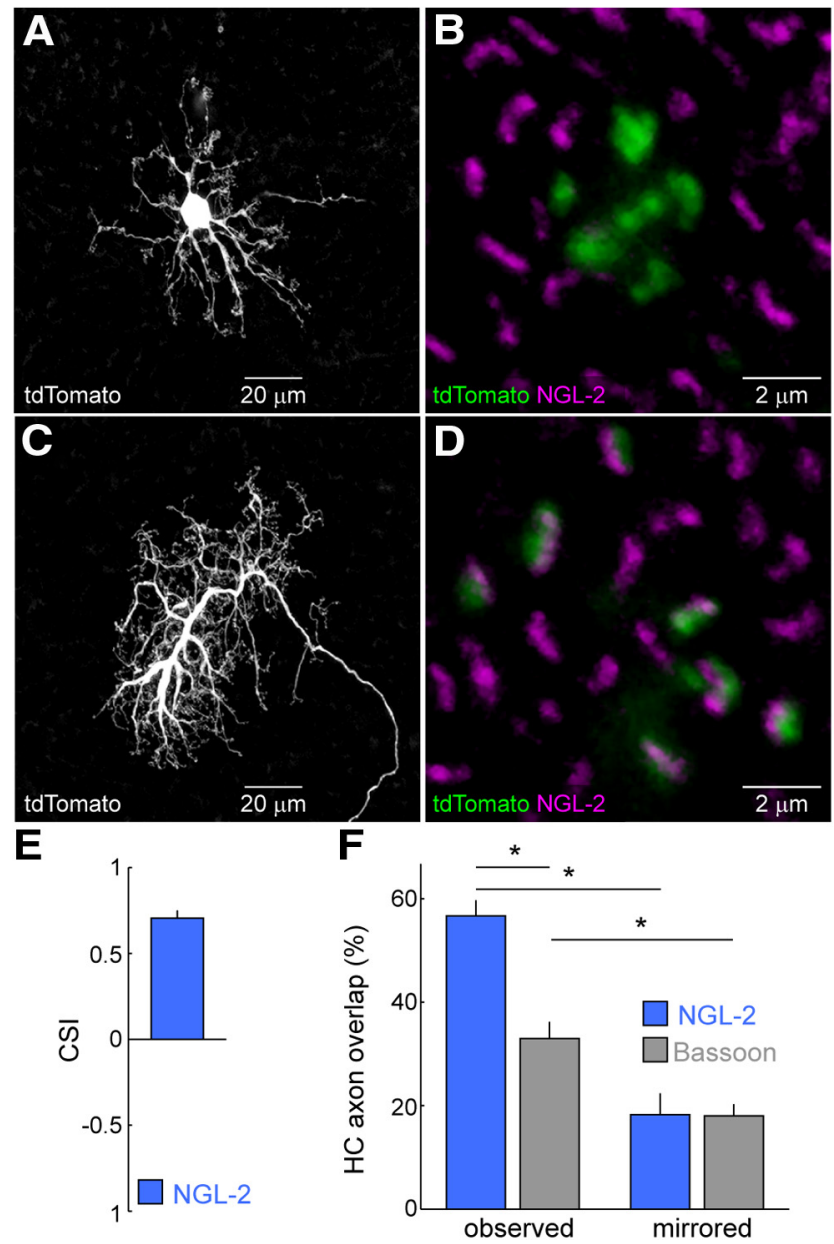

Figure 2. NGL-2 localizes selectively to the tips of $\mathrm{HC}$ axons. $A$, Maximum intensity projection (MIP) of a confocal image stack through the somatodendritic compartment of a representative HC expressing tdTomato in a double transgenic Cst-2A-Cre, Ai9 mouse. The tdTomato signal was amplified using an anti-DsRed antibody. $\boldsymbol{B}$, Magnified view of one dendritic cluster (green) of the cell in $\boldsymbol{A}$ and staining for NGL-2 (magenta) in a single optical section within the OPL. C, MIP of the axon of the same HC as in A. D, Magnified single plane view of several tips of the same axon arbor (green), which colocalize with staining for NGL-2 (magenta). $\boldsymbol{E}$, The distribution of NGL-2 between synapses of HC axons versus dendrites quantified by the CSI (see Materials and Methods, $n=4$ cells). $\boldsymbol{F}$, Comparison of the overlap of NGL-2 (blue, $n=4$ cells) and Bassoon (gray, $n=6$ cells) immunolabeling with $\mathrm{HC}$ axons (observed) confirm localization of NGL-2 to the postsynaptic specialization of HCs. Overlap of mirrored NGL-2 and Bassoon image stacks with $\mathrm{HC}$ axon tips was indistinguishable.

To analyze the subcellular distribution of NGL-2 in HCs, we masked the tips of $\mathrm{HC}$ axons and dendrites, respectively, in image stacks of retinal flat mount preparations from mice in which few HCs expressed a cytosolic fluorophore (tdTomato, see Results). We then multiplied the signal from immunolabeling of NGL-2, acquired in the same image stacks with the respective binary masks and defined a compartment selectivity index (CSI) as follows:

$$
\mathrm{CSI}=\frac{I_{\mathrm{Ax}}-I_{\mathrm{De}}}{I_{\mathrm{Ax}}+I_{\mathrm{De}}}
$$

In this, $I_{\mathrm{Ax}}\left(I_{\mathrm{De}}\right)$ indicates the background-subtracted average intensity of the NGL-2 staining within the masked axon (dendrite) tips of a given HC.

To compare the overlap of NGL-2, which we argue is expressed by HCs, and Bassoon, a marker of presynaptic release sites in PRs, with HC axons, we masked tips of $\mathrm{HC}$ axons as outlined above. In addition, the immunohistochemistry signals for NGL-2 and Bassoon were binarized using local thresholding. We then calculated the percentage of overlap of each tip with thresholded NGL-2 or Bassoon signals. To ensure fair com-
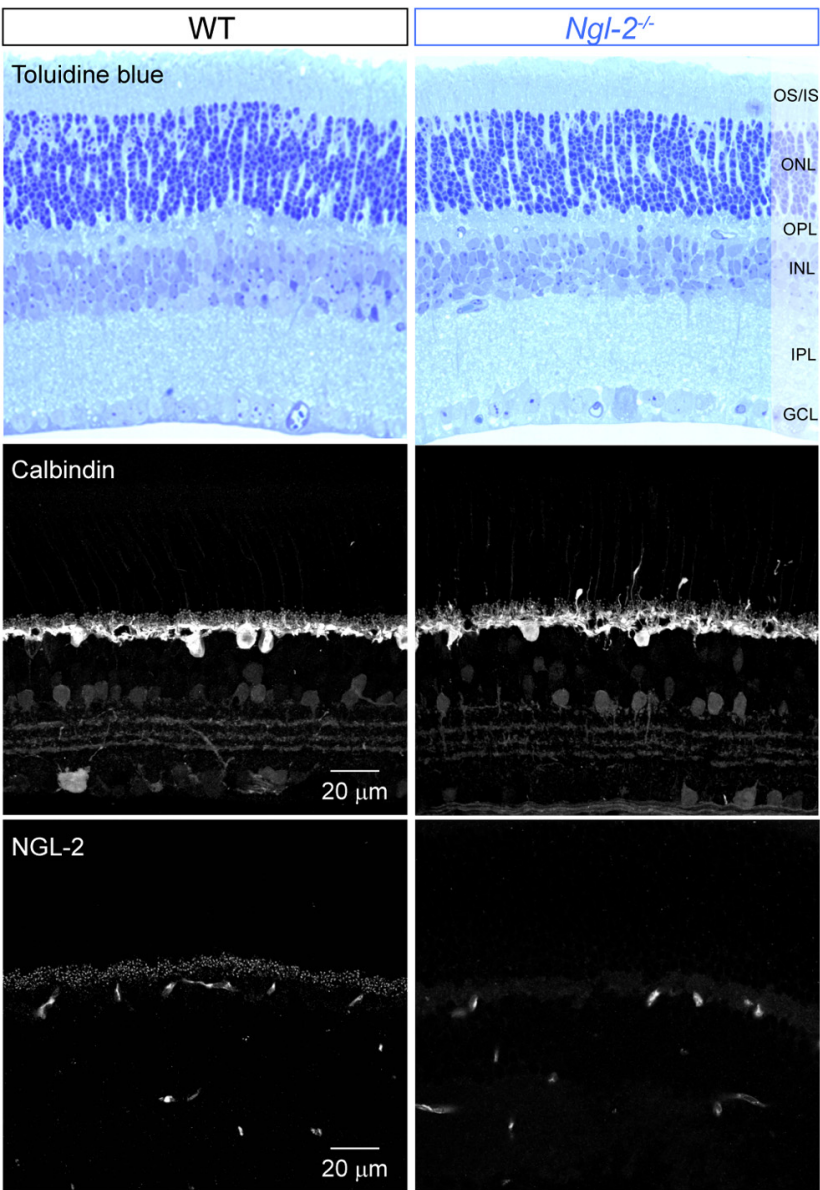

Figure 3. Preserved cytoarchitecture, misplaced $\mathrm{HC}$ neurites, and antibody specificity in $\mathrm{Ngl-2} 2^{-1-}$ retinas. Top row, Toluidine blue staining of retinal semithin sections from WT (left) and $\mathrm{Ngl}^{-2^{-/-}}$(right) mice illustrate preserved layering and cell numbers in the absence of NGL-2. Middle row, Calbindin immunohistochemistry of retinal vibratome sections shows misplaced HC neurites in the ONL of $\mathrm{Ngl}_{-2} 2^{-1-}$ (right) but not WT (left) mice at P25. Bottom row, Comparison of immunolabeling for NGL-2 in vibratome sections of P30 WT (left) and $\mathrm{Ngl}^{-2^{-1-}}$ (right) mice demonstrates the specificity of the anti-NGL-2 antibody.

parisons, we verified that the average overlaps of mirrored NGL-2 and Bassoon images with $\mathrm{HC}$ axons were not significantly different (see Fig. $2 F$ ).

The density recovery profile (DRP) of $\mathrm{HC}$ somata was calculated following the definition of Rodieck (1991) using previously described routines (Soto et al., 2012). Briefly, the density of HCs was measured in 5- $\mu \mathrm{m}$-wide annuli at increasing distance from a reference cell, with each $\mathrm{HC}$ in an image serving once as the reference cell. The extent of the exclusion zone around the reference cell in which other HCs are unlikely to be found (i.e., effective radius) was quantified as the radius of a cylinder of equal height to the average density and equal volume to the dip in a $3 \mathrm{D}$ plot of the DRP. HC dendrite and axon territories were measured as the area of the smallest convex polygon encompassing the respective arbors in a $z$-projection. Axon tips invading the outer nuclear layer (ONL) were counted as the number of neurites extending $>5 \mu \mathrm{m}$ beyond the median $z$-position of tips of in an axon arbor. Dendritic clusters of HCs were identified by eye based on their typical appearance (Raven et al., 2007) and colocalization with staining of fluorescently conjugated peanut agglutinin.

Electron microscopy. After fixation and rinsing in $0.1 \mathrm{M}$ sodium cacodylate ( $\mathrm{pH} 7.35$ ) retinas were postfixed in $1 \%$ osmium tetroxide for $1 \mathrm{~h}$ and stained en bloc with $1 \%$ uranyl acetate in $0.1 \mathrm{M}$ acetate buffer for $1 \mathrm{~h}$. Blocks were then dehydrated in a graded series of ethanol followed by propylene oxide and embedded in Araldite 6005 resin.

Semithin sections $(0.5-1 \mu \mathrm{m})$ were cut through the entire retina at the level of the optic nerve. Ultrathin sections $(50-90 \mathrm{~nm})$ were taken from a $600-800 \mu \mathrm{m}$ segment of retina adjacent to the optic nerve. Ultrathin sec- 
tions were poststained with uranyl acetate and lead citrate and viewed on a Hitachi H-7500 electron microscope.

Electroretinogram recordings. Electroretinogram (ERG) responses to brief light flashes $(<5$ $\mathrm{ms}$ ) were recorded from $\mathrm{Ngl}-2^{-/-}$mice and WT littermates (P30) using a UTAS Visual Electrodiagnostic Testing System (LKC Technologies). The experimenter was blinded to the genotype of the mice. Mice were dark adapted overnight. Under dim red light, mice were anesthetized with ketamine $(80 \mathrm{mg} / \mathrm{kg})$ and $x y-$ lazine $(15 \mathrm{mg} / \mathrm{kg})$. Pupils were then dilated with $1 \%$ atropine sulfate (Falcon Pharmaceuticals) and a contact lens containing the recording electrode was positioned on the corneal surface of each eye. A heating pad controlled by a rectal temperature probe maintained core body temperature. Reference and ground needle electrodes were placed subcutaneously at the vertex of the skull and the base of the tail, respectively. Mice were positioned inside a BigShot Ganzfeld dome for testing. For measurements of dark-adapted responses, stimuli were presented in order of increasing luminance from -4.60 to $+1.41 \log \mathrm{cd} \mathrm{s} \mathrm{m}^{-2}$. Interstimulus intervals ranged from $5 \mathrm{~s}$ at the lowest intensities to $90 \mathrm{~s}$ at the highest intensities. Mice were then adapted to a background light level of $30 \mathrm{~cd} \mathrm{~m}^{-2}$ for $10 \mathrm{~min}$. Subsequently, stimuli probing light-adapted responses were presented in order of increasing luminance from -0.01 to $+2.67 \log \mathrm{cd} \mathrm{s} \mathrm{m}{ }^{-2}$ in the presence of this constant background illumination. The interstimulus interval for photopic stimuli ranged from 1.33 to $3.33 \mathrm{~s}$.

At each light level 5-10 responses were averaged. The a-wave amplitude was measured as the difference between the response minimum in the first $50 \mathrm{~ms}$ following flash onset and the baseline value at flash onset. The b-wave amplitude was measured as the difference between the a-wave amplitude and a low-pass-filtered b-wave peak. The low-pass-filtered b-wave peak was determined as follows: responses were forward- and reverse-filtered using a fourth-order low-pass Butterworth IIR filter with cutoff frequencies ranging from 15 to $25 \mathrm{~Hz}$ (dark-adapted responses) or $25-30 \mathrm{~Hz}$ (lightadapted responses), including all integer values in those ranges. For each cutoff frequency, peak times and amplitudes of forward- and reversefiltered responses were averaged and a local maximum in the unfiltered response within $20 \mathrm{~ms}$ of the averaged peak times identified. The cutoff frequency that generated an average peak amplitude most similar to the unfiltered local maximum identified most frequently was selected and the difference between this value and the a-wave minimum reported as the b-wave amplitude. For all stimuli, oscillatory potential amplitudes were measured as the difference between the maximum and minimum values of the response after being forward-filtered by a fourth-order $80 \mathrm{~Hz}$-high-pass Butterworth IIR filter. All ERG analyses were implemented via scripts written in Matlab (MathWorks).

Statistics. Unless noted otherwise, statistical significance of differences between groups was assessed using Wilcoxon-Mann-Whitney rank sum tests. Throughout the text, summary data are presented as mean \pm SEM.

\section{Results}

NGL-2 is expressed by developing HCs and localizes to synapses between $\mathrm{HC}$ axons and rod photoreceptors To identify molecular cues that guide the formation of specific visual pathways, we analyzed the expression patterns of candidate genes encoding LRR-containing CAMs in the developing mouse retina. In situ hybridization of retinal slices revealed that $\mathrm{Ngl}-2$ mRNA is highly enriched in a sparse population of cells at the outer edge of the inner nuclear layer (INL) from P10 onwards (Fig. $1 A-C$ ). In addition, weak staining was detected in the inner portion of the INL and the ganglion cell layer (GCL) with a similar developmental time course. By combining in situ hybridization with immunohistochemistry for calbindin (Haverkamp and Wässle, 2000), we identified the neurons strongly expressing $\mathrm{Ngl}-2$ in the outer retina as HCs (Fig. 1D). Staining of retinal sections with a monoclonal antibody (Fig. $1 E, F$ ) next showed that NGL-2 protein localizes to the outer plexiform layer (OPL), where HCs form synapses with PRs and BCs (Masland, 2001; Wässle, 2004). NGL-2 levels in the OPL increase between P10 and P20 (i.e., shortly after the rise of $\mathrm{Ngl}-2$ transcription).

In mice, HCs form pathway-specific connections in the OPL: their dendrites exclusively contact cone PRs, whereas their axons selectively target rod PRs (Kolb, 1970, 1974). To determine whether NGL-2 is distributed evenly between both compartments of HCs, or restricted to synapses in rod or cone pathways, we crossed Cst-2A-Cre (Taniguchi et al., 2011) to fluorescent 
reporter mice (Ai9) (Madisen et al., 2010). This reliably labeled isolated HCs ( $\sim 4$ per retina) in double transgenic offspring (Fig. $2 A, C)$. Immunohistochemistry in flat mount preparations of the respective retinas (at $\mathrm{P} 21$ ) revealed that NGL-2 clusters at the tips of $\mathrm{HC}$ axons (Fig. 2D), but is mostly absent from $\mathrm{HC}$ dendrites (Fig. 2B). To quantify this observation we calculated the ratio of the difference between NGL-2 labeling intensities in axon and dendrite tips to their sum [compartment selectivity index (CSI), see Materials and Methods]. A CSI of 1 would indicate purely axonal, -1 purely dendritic, and 0 even distribution between both compartments. The observed CSI of $0.71 \pm 0.04$ (mean \pm SEM, $n=4$, Fig. $2 E$ ) confirmed the preferential targeting of NGL-2 to contacts of HC axons with rod PRs.

$\mathrm{Ngl}-2$ transcripts in the outer retina were only detected in HCs, not PRs. To verify that the NGL-2 protein was similarly restricted to the postsynaptic specialization of $\mathrm{HC}$ axons rather than presynaptic release sites of rods, we compared the overlap of NGL-2 staining with $\mathrm{HC}$ axons to that of the ribbon anchoring protein Bassoon. In binarized projections through confocal image stacks of the OPL (see Materials and Methods), the overlap of NGL-2 was greater than that of Bassoon (NGL-2: $56.7 \pm 2.9 \%$, $n=8$ images stacks from 4 cells; Bassoon: $33.0 \pm 2.9 \%, n=12$ images stacks from 6 cells; $p<0.002$; Fig. $2 F$ ), while the overlap of mirrored NGL-2 and Bassoon projections with HC axons was not significantly different (NGL-2: $18.2 \pm 4.0 \%$; Bassoon: $18.0 \pm$ $2.2 \% ; p>0.8)$. Together, these results show that NGL-2 selectively localizes to $\mathrm{HC}$ axon tips in the OPL.

HCs in $\mathrm{Ngl-2} 2^{-/-}$mice establish normal soma distributions but mistarget neurites

The localization of NGL-2 to HC axon tips led us to hypothesize that it may regulate the development of neurites and/or synapses in a pathway-specific manner. To begin to test this hypothesis, we obtained mice lacking the single coding exon of the $\mathrm{Ngl}-2$ gene (Ngl-2 $2^{-/-}$mice) (Tang et al., 2010). Toluidine blue-stained semithin sections from P30 mice showed preservation of the retinal cytoarchitecture in $\mathrm{Ngl-2} 2^{-/}$mice (Fig. 3, top row). Immunohistochemistry for calbindin further demonstrated that HC somata are correctly positioned at the border between INL and OPL (Fig. 3, middle row). However, we found that processes of HCs frequently invade the ONL in $\mathrm{Ngl-} 2^{-/-}$but not WT retinas (P25), indicating a role for NGL-2 in neurite targeting. Staining for NGL-2 in P30 WT mice demonstrated stable expression of this protein in mature $\mathrm{HCs}$, while the lack of OPL signal in $\mathrm{Ngl-2}-1-$ mice confirmed the specificity of the respective antibody (Fig. 3, bottom row).

In addition to reaching precise laminar positions, developing HC somata attain regular lateral distributions (i.e., mosaics), which support spatially uniform connectivity in the OPL (Wässle, 2004; Whitney et al., 2011; Kay et al., 2012). To probe the influence of NGL-2 on the development of HC mosaics, we stained flat mounted $\mathrm{WT}$ and $\mathrm{Ngl-} 2^{-/-}$retinas (P21) for calbindin and analyzed the DRP of HCs (Fig. 4A-C) (Rodieck, 1991). Neither the density of HC somata (WT: $1210 \pm 74 / \mathrm{mm}^{2}, n=6$

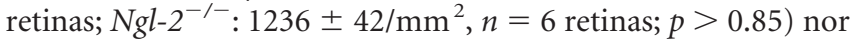
the regularity of their distribution, quantified as the effective radius of the DRP exclusion zone (see Materials and Methods), differed significantly between $\mathrm{Ngl}-2^{-/-}$mice and WT littermates (WT: $17.3 \pm 0.6 \mu \mathrm{m}, n=6$ retinas; $N g l-2^{-/-}: 19.2 \pm 0.9 / \mu \mathrm{m}, n=$ 6 retinas; $p>0.15$ ), arguing that NGL-2 is dispensable for formation of HC mosaics.

Orthogonal views of the confocal image stacks acquired in flat mount preparations confirmed the mislocalization of $\mathrm{HC}$ neu-
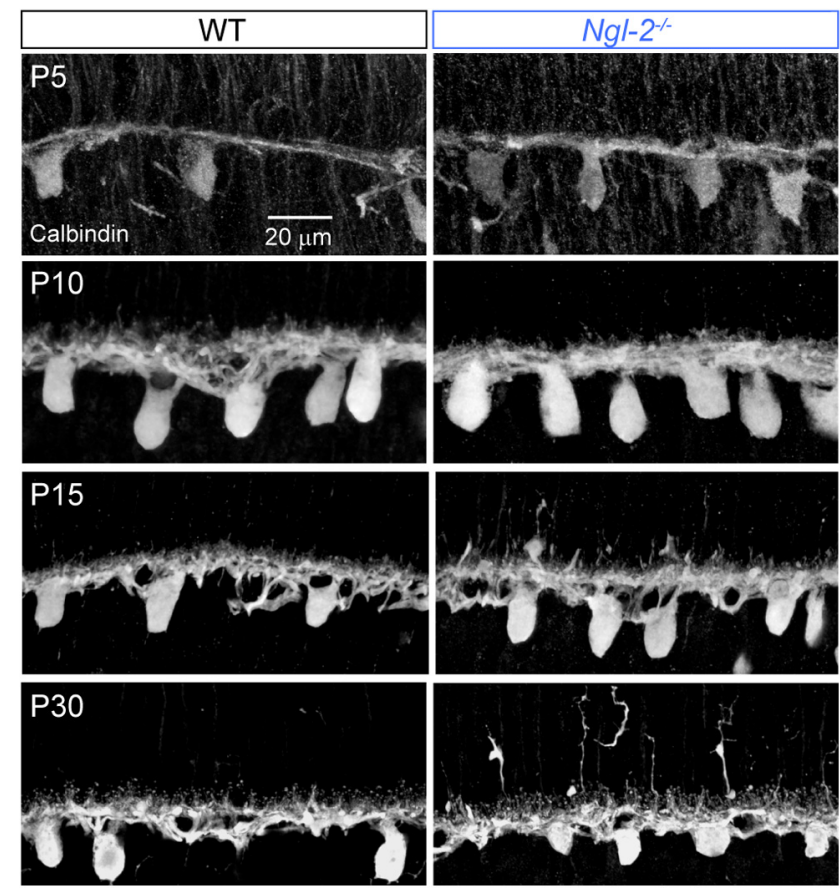

Figure 5. HCs mistarget axons after correct pruning of transient vertical processes in $\mathrm{Ngl}-2^{-1-}$ mice. Representative images of vibratome sections through retinas of WT (left column) and $\mathrm{Ngl}-2^{-/-}$(right column) at different postnatal ages (P5-30) stained for the $\mathrm{HC}$ marker calbindin. The elaboration of aberrant $\mathrm{HC}$ processes into the ONL is clearly seen in $\mathrm{Ngl}-2^{-/-}$retinas at P15 and P30.

rites in $\mathrm{Ngl-2} 2^{-/-}$mice (Fig. $\left.4 A, x-z\right)$. The observation that most misplaced neurites are immunopositive for neurofilament $(91 \pm$ $2 \%, n=13$ retinas) suggested that they are either remnants of migratory HC processes or mistargeted axons, but not dendrites (Peichl and González-Soriano, 1993; Haverkamp and Wässle, 2000; Lee et al., 2008; Huckfeldt et al., 2009; Matsuoka et al., 2012).

\section{HCs axons mistarget after correct pruning of transient} vertical processes in $\mathrm{Ngl}-2^{-/-}$mice

To reach their final laminar position, developing HCs migrate radially through the INL (Edqvist and Hallböök, 2004; Godinho et al., 2007; Poché et al., 2007; Huckfeldt et al., 2009). In support of this radial migration, HCs elaborate transient vertical neurites, which extend into the ONL (Reese et al., 2005; Huckfeldt et al., 2009; Matsuoka et al., 2012). In mice, these transient neurites are pruned around P5 when HC dendrites and axons grow in the OPL (Reese et al., 2005; Huckfeldt et al., 2009; Matsuoka et al., 2012). To determine whether HC neurites in the ONL of mature $\mathrm{Ngl}-2^{-/-}$mice arise from abnormal persistence of migratory processes or mistargeting of growing axons, we stained vibratome sections of WT and $\mathrm{Ngl-2} 2^{-/-}$retinas at different developmental stages for calbindin (Fig. 5). Similar to WT mice, HC neurites in $\mathrm{Ngl}-2^{-/}$retinas were restricted to the OPL at P5 and P10 indicating that transient vertical processes are correctly pruned in the absence of NGL-2. Subsequently (P15), HC neurites begin to invade the ONL of $\mathrm{Ngl-} 2^{-/-}$retinas, reaching their maximal extent $\sim$ P30. The timing of this phenotype matches the timing of protein expression in WT mice (Fig. $1 E, F$ ) and suggests that NGL-2 on the tips of growing $\mathrm{HC}$ axons helps guide their laminar targeting. 

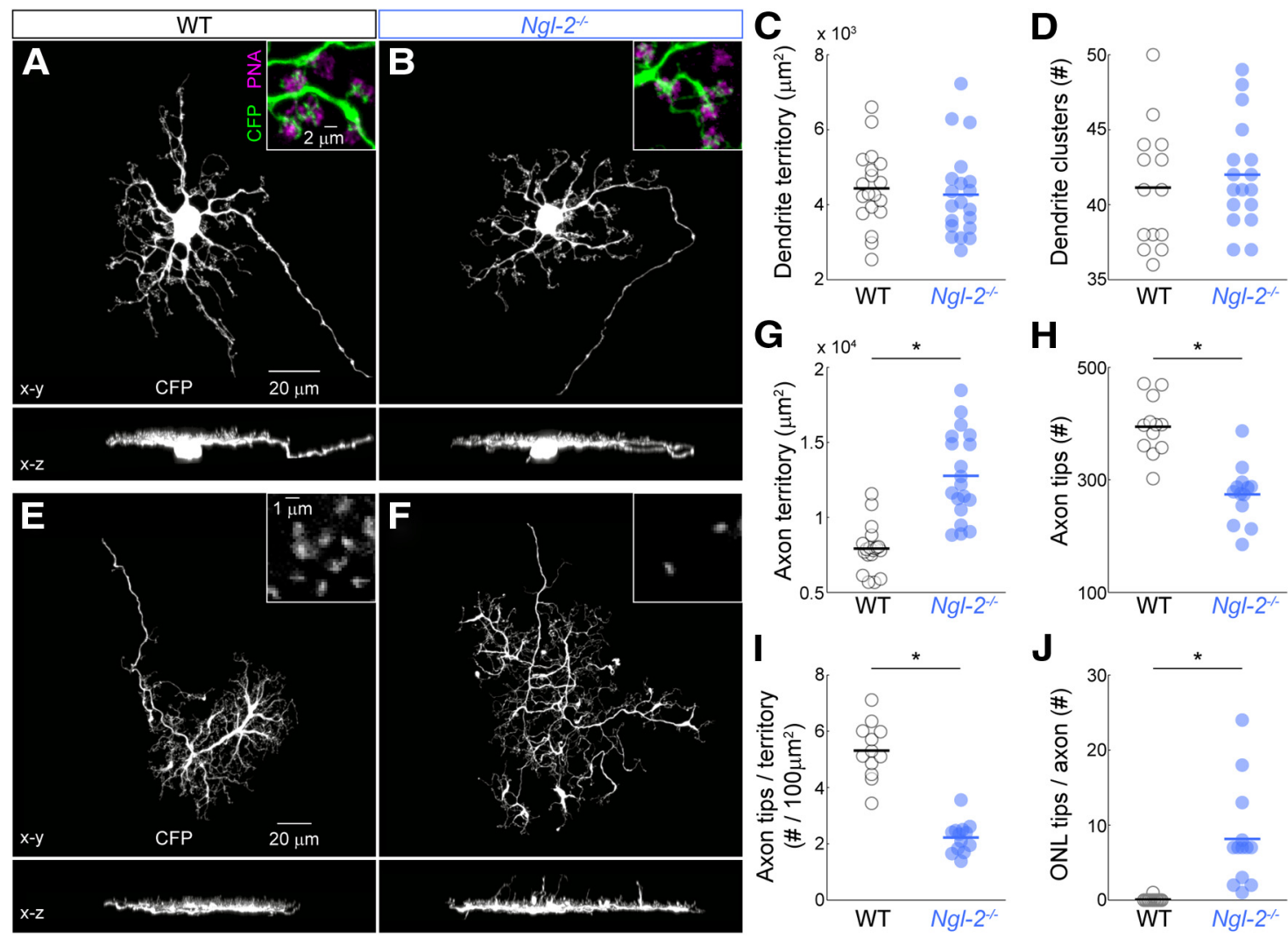

Figure 6. HC axons but not dendrites overgrow and form fewer synapses in Ngl-2 $2^{-1-}$ mice. $\boldsymbol{A}, \boldsymbol{B}, \mathrm{MIPs}$ along $z-(\boldsymbol{x}-\boldsymbol{y})$ and $y$-axes $(\boldsymbol{x}-\boldsymbol{z})$ of confocal image stacks through dendritic arbors of individual HCs labeled by viral gene delivery (AAV-CAG-CFP) in WT $(\boldsymbol{A})$ and $\mathrm{Ngl}-2^{-\prime-}(\boldsymbol{B})$ retinas. Insets show magnified views of a few contacts between the respective dendrites ( $g$ reen) and cone PR terminals labeled by fluorescent peanut agglutinin (magenta). C, D, Population data of territory sizes ( $\boldsymbol{C}$ ) and the number of synaptic clusters (D) of $\mathrm{HC}$ dendrites in WT (white) and $\mathrm{Ngl}-2^{-/-}$ (blue) mice. Throughout this figure, circles indicate the measurements of single cells and bold lines represent the mean of the respective populations. $\boldsymbol{E}, \boldsymbol{F}$, MIPs analogous to those in $\boldsymbol{A}$ and $\boldsymbol{B}$ through the axons of representative $H\left(\sin W T(E)\right.$ and $N g l-2^{-1-}(\boldsymbol{F})$ mice. Insets illustrate the differences in axon tip density between both genotypes via enlargements of single plane views of the respective image stacks. $\mathbf{G}-\boldsymbol{J}$, Summary data of $\mathrm{HC}$ axon territory sizes $(\boldsymbol{G})$, tip numbers $(\boldsymbol{H})$, tip densities $(\boldsymbol{I})$, and the numbers of misplaced branches $(\boldsymbol{J})$ in the $0 \mathrm{NL}$ of WT (white) and $\mathrm{Ng}-2^{-/-}($blue) retinas. ${ }^{*} p<0.001(\mathbf{G}-\mathbf{J})$.

HC axons overgrow laterally and vertically, and form fewer synapses in $\mathrm{Ngl}-2^{-/-}$mice

To further elucidate how NGL-2 shapes neurite growth and to begin to assess its contribution to synaptic development, we sparsely labeled $\mathrm{HCs}$ in $\mathrm{Ngl-} 2^{-/-}$and WT retinas by injecting adeno-associated viruses encoding cyan fluorescent protein $(A A V-C A G-C F P)$ into the vitreous humor of newborn (P0-2) mice. Morphological analyses of single HCs (P21-25) revealed that their dendrites occupy similar territories in WT and $\mathrm{Ngl-2} 2^{-/-}$ mice (Fig. $6 A-C$; WT: $4436 \pm 233 / \mu \mathrm{m}^{2}, n=19 ; \mathrm{Ngl-} 2^{-/-}$: $\left.4270 \pm 263 / \mu \mathrm{m}^{2}, n=20 ; p>0.39\right)$ and establish comparable numbers of synaptic contacts with cone terminals (Fig. $6 A, B, D$; WT: $\left.41.1 \pm 1.1, n=14 ; N g l-2^{-/-}: 42 \pm 0.9, n=17 ; p>0.56\right)$. Moreover, the structure of individual cone-apposed dendritic clusters appeared unchanged (Fig. 6A, $B$, insets) and no HC dendrites were observed in the ONL of $\mathrm{Ngl}_{-} 2^{-/-}$or WT mice (WT: $0 / 19$ cells; $N g l-2^{-/-}: 0 / 20$ cells).

On the contrary, $\mathrm{HC}$ axon territories were enlarged in Ngl-2 $2^{-/-}$mice (Fig. 6E-G; WT: $7914 \pm 354 / \mu \mathrm{m}^{2}, n=19 ; \mathrm{Ngl}^{-2^{-/-}}$: $\left.12,777 \pm 672 / \mu \mathrm{m}^{2}, n=19 ; p<0.001\right)$. The tips of HC axons penetrate rod spherules to form synaptic contacts (RaoMirotznik et al., 1995). To study synapse patterns in this pathway, we therefore counted the number of HC axon tips in the OPL, confirming their postsynaptic differentiation by staining for the AMPA receptor subunit GluR2 (data not shown) (Hack et al., 2001; Pan and Massey, 2007). This analysis revealed that despite increased territories, $\mathrm{HC}$ axons develop fewer putative synapses in $\mathrm{Ngl-2} 2^{-/-}$retinas (Fig. $6 \mathrm{E}, \mathrm{F}$, insets, $\mathrm{H}$; WT: $395 \pm 15, n=12$; Ngl-2 $\left.2^{-/-}: 274 \pm 14, n=13 ; p<0.001\right)$ as a result of a $>2$-fold reduction in tip density (Fig. 6I; WT: $5.31 \pm 0.29 / 100 \mu \mathrm{m}^{2}, n=$ 19; $\left.N g l-2^{-1-}: 2.22 \pm 0.16 / 100 \mu \mathrm{m}^{2}, n=19 ; p<0.001\right)$. In agreement with the results of our calbindin and neurofilament immunohistochemistry (Figs. 3, 4, 5), branches of $A A V-C A G$ $C F P$-labeled HC axons lacking NGL-2 frequently invaded the ONL (Fig. 6F, J; WT: $0.08 \pm 0.08$ ONL tips/axon, $n=12 ; \mathrm{Ngl}$ $2^{-/-}: 8.15 \pm 1.85$ ONL tips/axon, $n=13 ; p<0.001$ ).

We used electron microscopy to verify that the reduced number of $\mathrm{HC}$ axon tips in $\mathrm{Ngl-} 2^{-/-}$mice indeed reflects a decrease in the number synapses with rod PRs. In ultrathin sections, we evaluated each rod spherule and cone pedicle encountered for the presence or absence of penetrating $\mathrm{HC}$ processes (Fig. $7 A, B$ ). Both in WT and $\mathrm{Ngl}-2^{-/-}$retinas, the vast majority of sections through cone pedicles contained HC dendrites (Fig. 7B; WT: 52/56 cones, $n=4$ retinas; $N g l-2^{-/-}: 36 / 38$ cones, $n=4$ retinas; $p>0.8 \chi^{2}$ test). By contrast, the fraction of rod spherules devoid of $\mathrm{HC}$ processes was increased in $\mathrm{Ngl}-2^{-/-}$mice compared with WT littermates. (Fig. $7 A, B$; WT: 220/735 rods, $n=4$ retinas; $N g l-2^{-/-}: 296 / 515$ rods, $n=4$ retinas; $p<0.001 \chi^{2}$ test).

Thus, NGL-2 localizes selectively to HC axons, guides their laminar targeting, restricts their lateral growth, and promotes the formation of pathway-specific synapses between $\mathrm{HC}$ axons and rod PRs. 
A

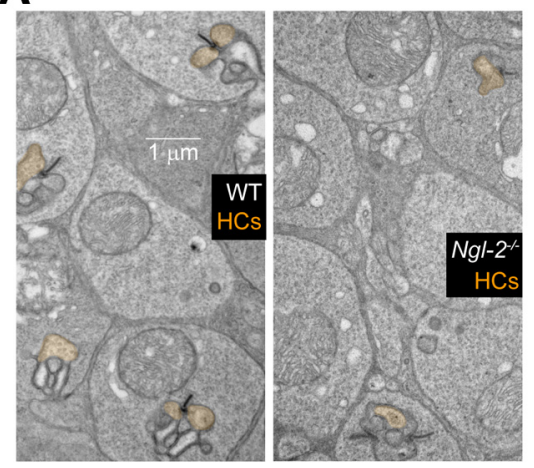

B $\square$-HC $\square \square+H C$

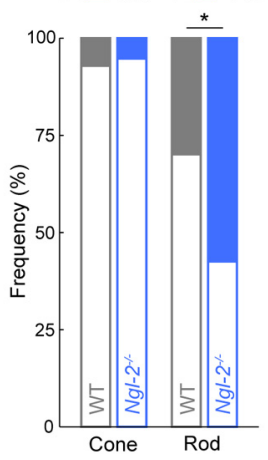

Figure 7. An increased fraction of rod spherules lack $\mathrm{HC}$ neurites in $\mathrm{Ngl-} 2^{-/-}$mice. $\boldsymbol{A}$, Representative electron micrographs from the OPL of WT (left) and $\mathrm{Ngl}^{-2^{-/}}$(right) mice. Penetrating $\mathrm{HC}$ processes are highlighted in orange. $\boldsymbol{B}$, Summary data of the fractions of cone pedicles and rod spherules containing or lacking $H C$ neurites in ultrathin sections of WT and $\mathrm{Ngl-} 2^{-1-}$ retinas. ${ }^{*} p<0.001 \chi^{2}$ test.

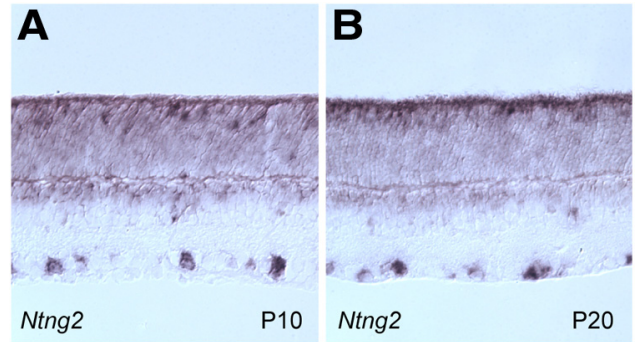

Figure 8. Ntng2 mRNA expression in the postnatal retina. $A, B, N$ tng2 transcripts are detected ubiquitously in cells of the ONL, as well as in cells in the outer part of the INL (i.e., the characteristic location of $B($ somata) and a sparse population of cells in the $\mathrm{GCL}$. Expression levels and patterns of Ntng2 mRNA appear stable between P10 (A) and P20 (B).

\section{Synaptic partners of HCs express netrin-G2}

Postsynaptic NGL-2 has been shown to interact specifically with presynaptic netrin-G2 (gene: Ntng2) in vitro and in vivo (Kim et al., 2006; Nishimura-Akiyoshi et al., 2007; Zhang et al., 2008; DeNardo et al., 2012), and reverse (i.e., netrin-G2-mediated) signaling of these complexes can promote presynaptic differentiation in coculture assays (Kim et al., 2006). We therefore wanted to test whether synaptic partners of HCs express netrin-G2 and evaluate how their development is affected by removal of NGL-2 in vivo. In situ hybridization revealed that Ntng2 transcripts are abundantly expressed by PRs in the ONL and in cells located in the outer half of the INL, the characteristic position of BC somata during postnatal development and at maturity (Fig. 8).

\section{$\mathrm{BC}$ dendrites and synapses laminate correctly in the OPL of} $\mathrm{Ngl}-2^{-/-}$mice

During development (Morgan et al., 2006) as well as in mature retinas of mouse mutants with disrupted glutamate release from PRs (Dick et al., 2003; tom Dieck et al., 2012), BC dendrites frequently associate with misplaced HC neurites in the ONL. Given these observations and the expression of Ntng2 in BCs (Fig. 8 ), we costained retinal sections for calbindin and different markers of BCs to compare laminar targeting of BC dendrites in WT and $\mathrm{Ngl-} 2^{-/-}$mice (P30). Staining for PKC $\alpha$, a specific marker of RBCs (Haverkamp and Wässle, 2000), and calbindin showed that OPL targeting of $\mathrm{RBC}$ dendrites in $\mathrm{Ngl-} 2^{-/-}$retinas is preserved, even in areas where HCs invade the ONL (Fig. 9, first row). Similarly, staining for G $\alpha$ o (Fig. 9, second row), which labels all ON
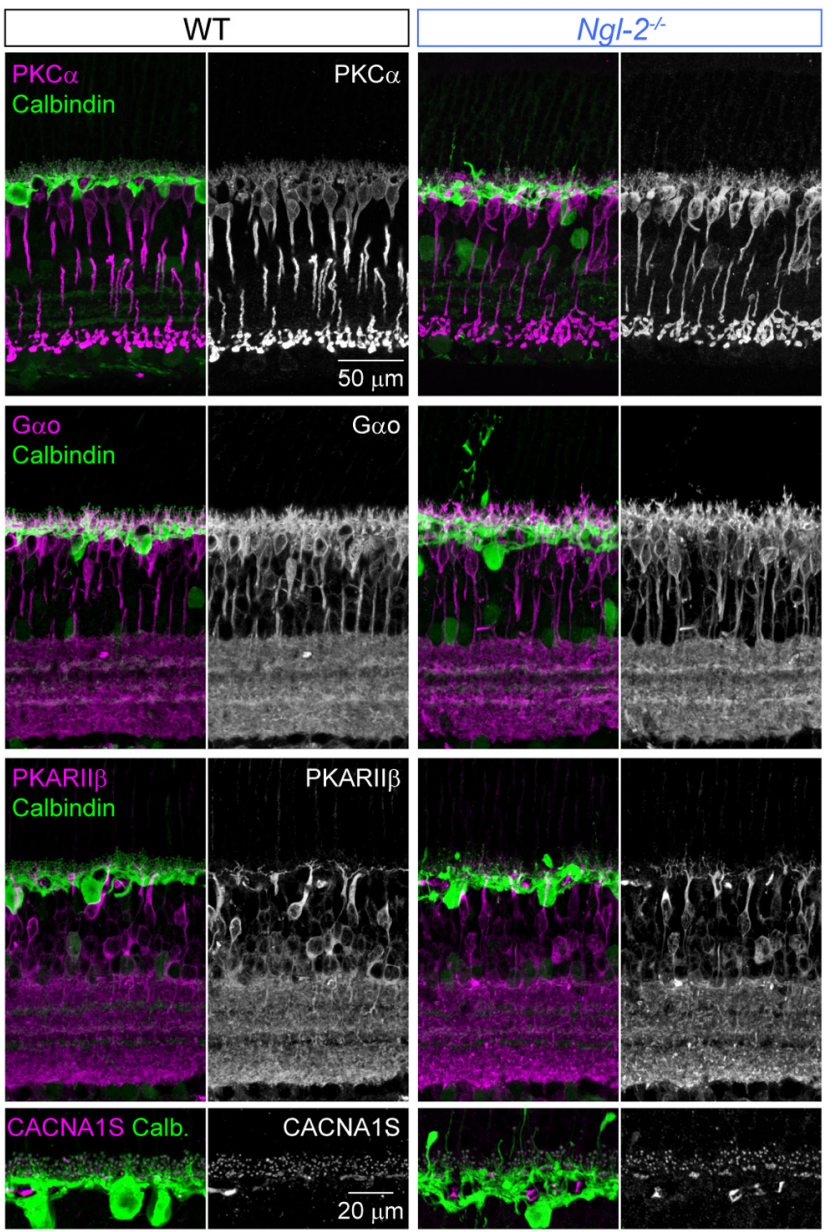

Figure 9. $B C$ dendrites and synapses stratify normally in the $\mathrm{OPL}$ of $\mathrm{Ngl}_{-2^{-1-}}$ mice. Costaining of P30 WT (left) and $\mathrm{Ngl-2} 2^{-1-}$ (right) retinal vibratome sections for calbindin and markers of different sets of $\mathrm{BCS}$ : first row PKC $\alpha-\mathrm{RBC}$, second row $\mathrm{G} \alpha 0-\mathrm{ON} \mathrm{BC}$, third row PKARIII $\beta$ - type 3b OFF BCs. Fourth row, CACNA1S, a component of the postsynaptic density of ON BCs, shows preserved stratification of synapses in the OPL of $\mathrm{Ngl}^{-2^{-1-}}$ (right) compared with WT mice (left).

BCs (Vardi, 1998; Huang et al., 2003), and PKARII $\beta$ (Fig. 9, third row), which marks type $3 \mathrm{~b}$ OFF BCs, a CBC type that also contacts rods (Mataruga et al., 2007; Wässle et al., 2009), revealed intact stratification of the dendrites of these BC types in $\mathrm{Ngl-2}-1-$ mice. Finally, immunolabeling of the $\alpha$ subunit $1 S$ of voltagegated calcium channels (CACNA1S), which localizes to synapses of ON BC dendrites, showed that connections onto these neurons were appropriately restricted to the OPL in both WT and $\mathrm{Ngl-} 2^{-1-}$ retinas (Fig. 9, fourth row).

PR terminals and synapses stratify normally but show disrupted ribbon assembly in rods of $\mathrm{Ngl-2} 2^{-/-}$mice

To evaluate the lamination of PR terminals, we costained retinal sections for cone arrestin, a specific marker of cones (Zhu et al., 2002), and the vesicular glutamate transporter VGluT1 used by both rods and cones (Johnson et al., 2003). As in WT retinas, rod spherules and cone pedicles labeled in this way form a tight band between the ONL and INL in $\mathrm{Ngl-} 2^{-/-}$mice (Fig. $10 \mathrm{~A}$, left column), demonstrating that PR axons target the OPL independent of the presence of NGL-2 on HCs. Similarly, the ribbonanchoring protein Bassoon (Dick et al., 2003) remained restricted to the OPL in $\mathrm{Ngl}-2^{-/-}$retinas (Fig. $10 \mathrm{~B}$, right column). Together with the normal distribution of CACNA1S (Fig. 9), this 
A

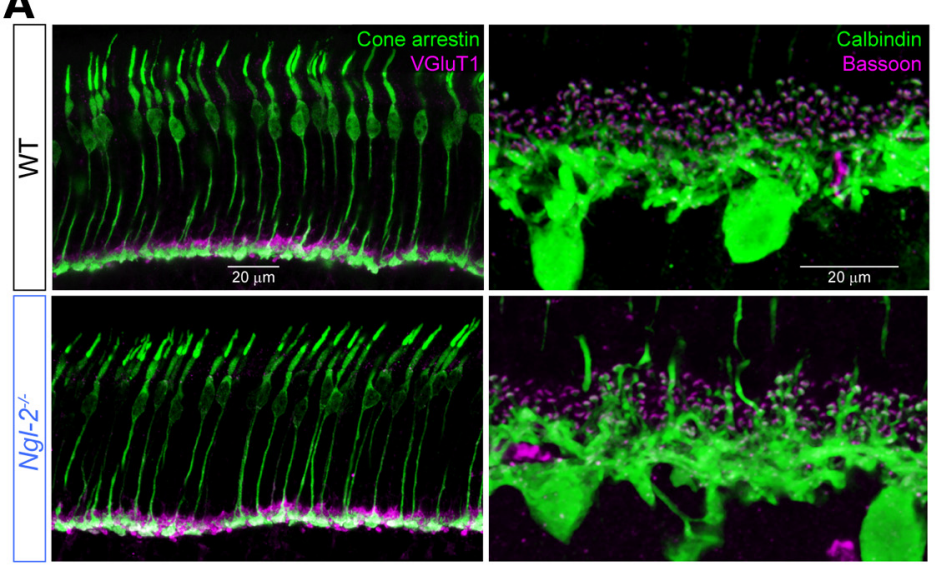

B

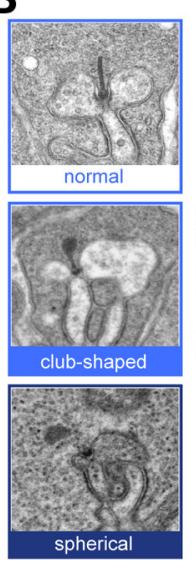

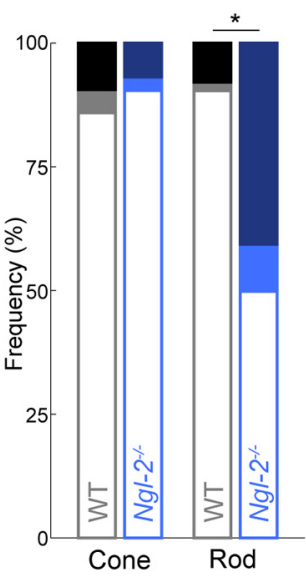

Figure 10. PR terminals correctly target the OPL, but rods show disrupted ribbon assembly in $\mathrm{Ngl-2} 2^{-1-}$ mice. $A$, MIPs of representative confocal image stacks from vibratome slices of P30 WT (top row) and $\mathrm{gll}_{-2} 2^{-1-}$ (bottom row) retinas costained for cone arrestin and VGluT1 (left column) or calbindin and bassoon (right column). $\boldsymbol{B}$, Exemplary electron micrographs (left) and summary data (right) of the ribbon structures in cone pedicles and rod spherules. The relative abundances of normally shaped anchored ribbons (top left), club-shaped anchored ribbons (middle left), and spherical free-floating ribbons (bottom left) are shown in green, yellow, and red, respectively. ${ }^{*} p<0.001 \chi^{2}$ test.

indicates that synapses between PRs, BCs, and HCs are correctly positioned in the OPL of $\mathrm{Ngl-2} 2^{-/-}$mice and argues against the formation of ectopic connections on mislocalized HC axon tips.

To further investigate a potential role for reverse signaling of transsynaptic complexes involving NGL-2 in the development of rod and/or cone PRs, we analyzed the ultrastructure of presynaptic release sites in electron micrographs. Presynaptic ribbons are assembled from electron dense precursor spheres (Blanks et al., 1974; Regus-Leidig et al., 2009). In WT mice, the number of anchored ribbons reaches a maximum $\sim$ P30 and precursor spheres or club-shaped intermediates of ribbon assembly are rarely observed at this age (Regus-Leidig et al., 2009). Comparing ribbon structures between WT and $\mathrm{Ngl}_{-} 2^{-/-}$mice at P30, we found that in cone terminals of either genotype the majority of ribbons were normally shaped and anchored at arciform densities (Fig. 10C; WT: 73 normal, 4 club-shaped, 8 spherical, $n=4$ retinas; $N g l-2^{-/-}: 66$ normal, 2 club-shaped, 5 spherical, $n=4$ retinas; $p>0.66, \chi^{2}$ test). By contrast, in rod terminals of $\mathrm{Ngl}$ $2^{-/-}$mice the fraction of spherical and club-shaped ribbons was increased several-fold (Fig. 10C; WT: 422 normal, 8 club-shaped, 37 spherical, $n=4$ retinas; $N g l-2^{-/-}: 152$ normal, 29 clubshaped, 124 spherical, $n=4$ retinas; $p<0.001, \chi^{2}$ test). The diameter of spherical ribbons was comparable between WT and $\mathrm{Ngl-} 2^{-/-}$retinas (WT: $167 \pm 11 \mathrm{~nm} ; \mathrm{Ngl}_{-} 2^{-/-}: 172 \pm 7 \mathrm{~nm}, \mathrm{p}>$ 0.39 ) and matched the previously reported size of precursor spheres (Regus-Leidig et al., 2009). These results support the notion that reverse signaling from HCs to rod PRs via transsynaptic complexes involving NGL-2 regulates presynaptic maturation.

\footnotetext{
$\mathrm{Ngl-2}-/-$ retinas display pathway-specific dysfunction in light-evoked signaling

Because NGL-2 appears to guide neurite growth and synapse development of $\mathrm{HC}$ axons but not dendrites, and regulates the assembly of presynaptic ribbons in rod but not cone PRs, we wanted to test whether similarly pathway-specific alterations in signal transmission accompany the morphological changes of $\mathrm{Ngl}-2^{-/-}$retinas. Toward this end, we recorded in vivo ERG responses to light flashes of varying intensities in dark- and lightadapted WT and $\mathrm{Ngl-} 2^{-/-}$mice (P30; Fig. 11). Comparisons of representative traces (Fig. 11A) and population data (Fig. 11B) from dark-adapted animals show that a-wave amplitudes-in-
}

dicative of rod responses - of $\mathrm{Ngl}-2^{-/-}$mice were indistinguishable from WT littermates. By contrast, b-wave amplitudes, were consistently decreased in dark-adapted $\mathrm{Ngl}^{-1-} 2^{-1}$ mice (Fig. $11 \mathrm{~B}$, ${ }^{*} p<0.05$ ANOVA test, $n=6 \mathrm{WT}$ and $6 \mathrm{Ngl}-2^{-/-}$mice), indicating abnormal transmission of responses from rod PRs to RBCs (Peachey and Ball, 2003; McCall and Gregg, 2008). Light-adapted b-wave amplitudes, on the other hand, which probe transmission of cone signals to $\mathrm{ON}$ cone BCs, were mostly intact (Fig. 11B). Thus, visual function in the outer retina of $\mathrm{Ngl}_{-} 2^{-1-}$ mice is disrupted in a pathway-specific manner, consistent with the observed anatomical changes.

Interestingly, oscillatory potentials (OPs) isolated by highpass filtering of ERG responses $(>80 \mathrm{~Hz})$ were reduced in both dark- and light-adapted $\mathrm{Ngl-2} 2^{-/-}$mice compared with WT littermates (Fig. $11 C,{ }^{\star} p<0.05$ ANOVA test). OPs are thought to reflect activation of third order neurons (i.e., amacrine and ganglion cells) in the inner retina (Wachtmeister, 1998). While the decrease in OPs of dark-adapted $\mathrm{Ngl-} 2^{-/-}$mice could be secondary to lower RBC responses, we interpret reduced light-adapted OPs to reflect changes in inner retinal function, which may be related to the expression of $\mathrm{Ngl}-2$ in amacrine cells observed by in situ hybridization (Fig. 1) and indicate a distinct role of NGL-2 in the development of circuits in the inner retina.

\section{Discussion}

In this study, we find that the LRR-containing protein NGL-2 directs several aspects of pathway-specific connectivity in the outer retina. The mouse retina has a single type of HCs (Peichl and González-Soriano, 1994). In the OPL, axons of these HCs form synapses with rod PRs, whereas HC dendrites connect to cones (Kolb, 1970, 1974). We show that NGL-2 is expressed selectively on the axon tips of developing and mature HCs and identify pathway-specific defects in the development of $\mathrm{HC}$ axons, rod synapses, and signal transmission in the outer retina of $\mathrm{Ngl-2}-1-$ mice.

\section{NGL-2 guides laminar targeting of $\mathrm{HC}$ axons}

In the absence of NGL-2, many HC axon branches overshoot their laminar target (i.e., the OPL) and invade the ONL (Figs. 3, 4, $5,6)$. A similar phenotype with $\mathrm{HC}$ axon mistargeting and over- 

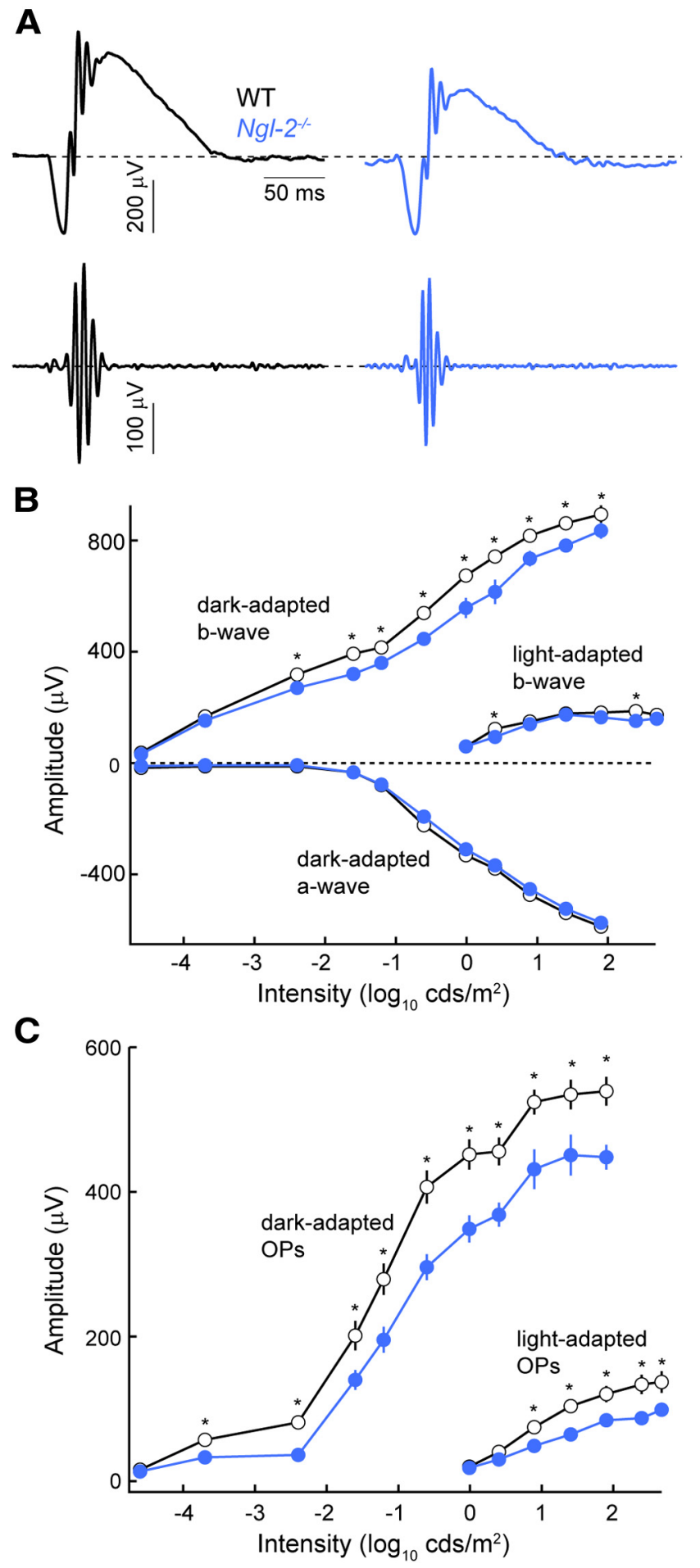

Figure 11. ERG recordings reveal pathway-specific changes in visual signaling in $\mathrm{Ngl-2} 2^{-/-}$retinas. $\boldsymbol{A}$, Unfiltered (top traces) and high-pass filtered (cutoff: $80 \mathrm{~Hz}$, bottom traces) representative responses of dark-adapted WT (black traces) and $\mathrm{Ngl}-2^{-1-}$ (blue traces) retinas to light flashes (2.526 $\left.\mathrm{cd} \mathrm{s} \mathrm{m}^{-2}\right) \cdot \boldsymbol{B}$, Summary data of dark-adapted a- and b-wave and light-adapted b-wave amplitude responses functions in WT (white circles, $n=6$ mice) and $\mathrm{Ngl}_{-} 2^{-/-}$mice (blue circles, $n=6$ mice). Circles (error bars) show the mean ( \pm SEM) of the respective populations. C, Population data (mean \pm SEM) of oscillatory potentials recorded in dark- and light-adapted conditions. Color-coding as in $\boldsymbol{B}$. Throughout this figure * indicates $p<0.05$ ANOVA test.

growth into ONL was recently reported for mice lacking specific components of semaphorin-plexin signaling $\left(S e m a 6 A^{-/-}\right.$, PlexA $4^{-/-}$) (Matsuoka et al., 2012). In contrast to NGL-2, which localizes to axon tips (Fig. 2) and likely interacts with netrin-G2
(Fig. 8) and possibly other proteins across the synaptic cleft (Kim et al., 2006; Nishimura-Akiyoshi et al., 2007; Zhang et al., 2008; DeNardo et al., 2012), Sema6A and PlexA4 are both expressed in HCs and distribute evenly along their neurites (Matsuoka et al., 2012). Together, these observations suggest that appropriate laminar targeting of $\mathrm{HC}$ axons requires both homotypic interactions within and/or among HCs, as well as heterotypic transsynaptic interactions.

Stratification of BC dendrites and PR terminals is preserved in $\mathrm{Ngl-} 2^{-/-}$, PlexA4 ${ }^{-/-}$, and Sema6A ${ }^{-/-}$mice (Figs. 9, 10) (Matsuoka et al., 2012). By contrast, in several mouse mutants with disrupted glutamate release from PRs, HC neurites and BC dendrites invade the ONL, often together (Dick et al., 2003; Haeseleer et al., 2004; Chang et al., 2006; Wycisk et al., 2006; tom Dieck et al., 2012). In conjunction with the fact that PR terminals stratify before $\mathrm{HC}$ neurites and $\mathrm{BC}$ dendrites in the developing OPL (Blanks et al., 1974; Morgan et al., 2006; Huckfeldt et al., 2009), this suggests a leading role for PRs in OPL lamination. In this context, our results indicate that, in addition to activity-mediated interactions, PRs instruct lamination of $\mathrm{HC}$ axons through transsynaptic complexes involving NGL-2.

\section{NGL-2 regulates lateral growth and retinal coverage of HC axons}

Whereas transient vertical neurites of migrating HCs are strictly territorial, a behavior that is thought to help establish mosaic distributions of HC somata (Huckfeldt et al., 2009), mature axons and dendrites of HCs overlap several-fold (Reese et al., 2005). Across different mouse strains, territories of HC dendrites have been shown to vary in size inversely to the density of HCs (Reese et al., 2005; Whitney et al., 2011). This presumably serves to establish constant retinal coverage and spatially uniform connectivity with cone PRs in the OPL. In support of the latter notion, changing the density of afferents was found to alter the size of $\mathrm{HC}$ dendrites and axons in an input-specific manner (Reese et al., 2005; Raven et al., 2007). The molecular mechanisms by which homotypic neighbors or afferents regulate neurite growth of HCs remained unknown. Here, we find that in $\mathrm{Ngl}-2^{-/-}$mice territories of HC axons, but not dendrites, expand (Fig. 6). Because the number and distribution of HCs does not differ between $\mathrm{Ngl-} 2^{-/-}$and WT mice, axonal coverage of the retina is increased (WT $\sim 9.6, \mathrm{Ngl}-2^{-/-}$ $\sim 15.8$ ). Thus, signaling involving NGL-2 restricts the growth of HC axons and appears to mediate an input-specific afferent influence that determines mature arbor size. Cumulative growth inhibiting signals initiated at synaptic contacts, in principle, provide an appealingly simple way for developing neurites to recruit a relatively constant number of inputs. The observation that dendrites of developing Drosophila aCC neurons grow when the density of input partners is reduced and shrink when it is increased, suggests that signals serving similar functions may act in a variety of systems (Tripodi et al., 2008).

Interestingly, two transmembrane proteins, MEGF10 and MEGF11, were recently shown to regulate $\mathrm{HC}$ mosaic spacing but not neurite growth (Kay et al., 2012), and PlexA4-Sema6A interactions were found to mediate homotypic neurite repulsion, but not to affect soma distributions. Together with our results, these studies suggest that separate molecular mechanisms guide neurite growth and soma positioning of HCs. This may differ from other cell types in the retina (Fuerst et al., 2008, 2009; Keeley et al., 2012). 


\section{NGL-2 promotes synapse formation and maturation in a bidirectional pathway-specific manner}

Despite their increased territories, HC axons develop fewer spine-like protrusions and a larger fraction of rod spherules lack HC insertions in the absence of NGL-2 (Figs. 6, 7). A similar reduction in the number of postsynaptic spines was previously observed in hippocampal neurons following $\mathrm{Ngl}-2$ knockdown in culture or knock-out in vivo (Kim et al., 2006; DeNardo et al., 2012). NGL-2 contains an intracellular PDZ-domain that interacts with scaffolding proteins including PSD-95, and the synaptogenic potential of NGL-2 was shown to require an intact PDZ-domain (Kim et al., 2006; DeNardo et al., 2012). Recruitment of scaffolding proteins to nascent excitatory synapses is known to promote synapse maturation and regulate the number of stable connections (El-Husseini et al., 2000). Given the expression pattern of scaffolding proteins in the outer retina (Koulen et al., 1998a, b), we propose that NGL-2 may promote the formation of $\mathrm{HC}$ axon synapses by interacting with SAP102. Future experiments are needed to test this hypothesis and explore alternative downstream targets of NGL-2.

Transsynaptic adhesion complexes frequently signal in both directions (Siddiqui and Craig, 2011). Postsynaptic NGL-2 interacts with presynaptic netrin-G2 (Kim et al., 2006; NishimuraAkiyoshi et al., 2007; Zhang et al., 2008; DeNardo et al., 2012), which we find to be expressed by PRs and likely BCs in the retina (Fig. 8). In coculture assays, expression of NGL-2 in nonneuronal cells induces presynaptic differentiation in contacting axons (Kim et al., 2006). We therefore tested whether NGL-2 has a role in presynaptic PR maturation. PRs release glutamate from specialized ribbon synapses. During development, presynaptic ribbons are assembled from precursor spheres and anchored to specialized active zones (arciform densities) (Regus-Leidig et al., 2009). While ribbon-anchoring proteins have been identified (Dick et al., 2003), the signals that trigger assembly of ribbons in alignment with postsynaptic specializations remained unknown. The rod-specific persistence of precursor spheres and reduction in the number of anchored ribbons we observe in $\mathrm{Ngl}_{-} 2^{-/-}$mice (Fig. 10) suggests that reverse signaling of transsynaptic complexes involving NGL-2 and likely netrin-G2 contributes to ribbon assembly in rods. Importantly, defects in ribbon assembly in $\mathrm{Ngl}-2^{-/-}$mice lead to reduced signal transmission from rods to RBCs in dark-adapted mice in vivo (Fig. 11), highlighting the importance of NGL-2 to the development of pathway-specific visual function in the retina.

\section{References}

Bareyre FM, Garzorz N, Lang C, Misgeld T, Büning H, Kerschensteiner M (2011) In vivo imaging reveals a phase-specific role of STAT3 during central and peripheral nervous system axon regeneration. Proc Natl Acad Sci U S A 108:6282-6287. CrossRef Medline

Blanks JC, Adinolfi AM, Lolley RN (1974) Synaptogenesis in the photoreceptor terminal of the mouse retina. J Comp Neurol 156:81-93. CrossRef Medline

Chang B, Heckenlively JR, Bayley PR, Brecha NC, Davisson MT, Hawes NL, Hirano AA, Hurd RE, Ikeda A, Johnson BA, McCall MA, Morgans CW, Nusinowitz S, Peachey NS, Rice DS, Vessey KA, Gregg RG (2006) The nob2 mouse, a null mutation in Cacnalf: anatomical and functional abnormalities in the outer retina and their consequences on ganglion cell visual responses. Vis Neurosci 23:11-24. Medline

DeNardo LA, de Wit J, Otto-Hitt S, Ghosh A (2012) NGL-2 regulates inputspecific synapse development in CA1 pyramidal neurons. Neuron 76: 762-775. CrossRef Medline

de Wit J, Hong W, Luo L, Ghosh A (2011) Role of leucine-rich repeat proteins in the development and function of neural circuits. Annu Rev Cell Dev Biol 27:697-729. CrossRef Medline

Dick O, tom Dieck S, Altrock WD, Ammermüller J, Weiler R, Garner CC, Gundelfinger ED, Brandstätter JH (2003) The presynaptic active zone protein bassoon is essential for photoreceptor ribbon synapse formation in the retina. Neuron 37:775-786. CrossRef Medline

Edqvist PH, Hallböök F (2004) Newborn horizontal cells migrate bidirectionally across the neuroepithelium during retinal development. Development 131:1343-1351. CrossRef Medline

El-Husseini AE, Schnell E, Chetkovich DM, Nicoll RA, Bredt DS (2000) PSD-95 involvement in maturation of excitatory synapses. Science 290: 1364-1368. Medline

Fox K, Wong RO (2005) A comparison of experience-dependent plasticity in the visual and somatosensory systems. Neuron 48:465-477. CrossRef Medline

Fuerst PG, Koizumi A, Masland RH, Burgess RW (2008) Neurite arborization and mosaic spacing in the mouse retina require DSCAM. Nature 451:470-474. CrossRef Medline

Fuerst PG, Bruce F, Tian M, Wei W, Elstrott J, Feller MB, Erskine L, Singer JH, Burgess RW (2009) DSCAM and DSCAML1 function in selfavoidance in multiple cell types in the developing mouse retina. Neuron 64:484-497. CrossRef Medline

Godinho L, Williams PR, Claassen Y, Provost E, Leach SD, Kamermans M, Wong RO (2007) Nonapical symmetric divisions underlie horizontal cell layer formation in the developing retina in vivo. Neuron 56:597-603. CrossRef Medline

Hack I, Frech M, Dick O, Peichl L, Brandstätter JH (2001) Heterogeneous distribution of AMPA glutamate receptor subunits at the photoreceptor synapses of rodent retina. Eur J Neurosci 13:15-24. CrossRef Medline

Haeseleer F, Imanishi Y, Maeda T, Possin DE, Maeda A, Lee A, Rieke F, Palczewski K (2004) Essential role of $\mathrm{Ca}^{2+}$-binding protein 4, a Cav1.4 channel regulator, in photoreceptor synaptic function. Nat Neurosci 7:1079-1087. CrossRef Medline

Haverkamp S, Wässle H (2000) Immunocytochemical analysis of the mouse retina. J Comp Neurol 424:1-23. CrossRef Medline

Hirano AA, Brandstätter JH, Brecha NC (2005) Cellular distribution and subcellular localization of molecular components of vesicular transmitter release in horizontal cells of rabbit retina. J Comp Neurol 488:70-81. CrossRef Medline

Hirasawa H, Kaneko A (2003) pH changes in the invaginating synaptic cleft mediate feedback from horizontal cells to cone photoreceptors by modulating $\mathrm{Ca}^{2+}$ channels. J Gen Physiol 122:657-671. CrossRef Medline

Huang L, Max M, Margolskee RF, Su H, Masland RH, Euler T (2003) G protein subunit $\mathrm{G}$ gamma 13 is coexpressed with $\mathrm{G}$ alpha $\mathrm{o}, \mathrm{G}$ beta 3 , and G beta 4 in retinal ON bipolar cells. J Comp Neurol 455:1-10. CrossRef Medline

Huckfeldt RM, Schubert T, Morgan JL, Godinho L, Di Cristo G, Huang ZJ, Wong RO (2009) Transient neurites of retinal horizontal cells exhibit columnar tiling via homotypic interactions. Nat Neurosci 12:35-43. CrossRef Medline

Jackman SL, Babai N, Chambers JJ, Thoreson WB, Kramer RH (2011) A positive feedback synapse from retinal horizontal cells to cone photoreceptors. PLoS Biol 9:e1001057. CrossRef Medline

Johnson J, Tian N, Caywood MS, Reimer RJ, Edwards RH, Copenhagen DR (2003) Vesicular neurotransmitter transporter expression in developing postnatal rodent retina: GABA and glycine precede glutamate. J Neurosci 23:518-529. Medline

Kamermans M, Fahrenfort I, Schultz K, Janssen-Bienhold U, Sjoerdsma T, Weiler R (2001) Hemichannel-mediated inhibition in the outer retina. Science 292:1178-1180. CrossRef Medline

Kay JN, Chu MW, Sanes JR (2012) MEGF10 and MEGF11 mediate homotypic interactions required for mosaic spacing of retinal neurons. Nature 483:465-469. CrossRef Medline

Keeley PW, Sliff BJ, Lee SC, Fuerst PG, Burgess RW, Eglen SJ, Reese BE (2012) Neuronal clustering and fasciculation phenotype in Dscam- and Bax-deficient mouse retinas. J Comp Neurol 520:1349-1364. CrossRef Medline

Kim S, Burette A, Chung HS, Kwon SK, Woo J, Lee HW, Kim K, Kim H, Weinberg RJ, Kim E (2006) NGL family PSD-95-interacting adhesion molecules regulate excitatory synapse formation. Nat Neurosci 9:12941301. CrossRef Medline

Kolb H (1970) Organization of the outer plexiform layer of the primate retina: electron microscopy of Golgi-impregnated cells. Philos Trans R Soc Lond B Biol Sci 258:261-283. CrossRef Medline

Kolb H (1974) The connections between horizontal cells and photorecep- 
tors in the retina of the cat: electron microscopy of Golgi preparations. J Comp Neurol 155:1-14. CrossRef Medline

Koulen P, Garner CC, Wässle H (1998a) Immunocytochemical localization of the synapse-associated protein SAP102 in the rat retina. J Comp Neurol 397:326-336. CrossRef Medline

Koulen P, Fletcher EL, Craven SE, Bredt DS, Wässle H (1998b) Immunocytochemical localization of the postsynaptic density protein PSD-95 in the mammalian retina. J Neurosci 18:10136-10149. Medline

Lee EJ, Padilla M, Merwine DK, Grzywacz NM (2008) Developmental regulation of the morphology of mouse retinal horizontal cells by visual experience. Eur J Neurosci 27:1423-1431. CrossRef Medline

Madisen L, Zwingman TA, Sunkin SM, Oh SW, Zariwala HA, Gu H, Ng LL, Palmiter RD, Hawrylycz MJ, Jones AR, Lein ES, Zeng H (2010) A robust and high-throughput Cre reporting and characterization system for the whole mouse brain. Nat Neurosci 13:133-140. CrossRef Medline

Masland RH (2001) The fundamental plan of the retina. Nat Neurosci 4:877-886. CrossRef Medline

Mataruga A, Kremmer E, Müller F (2007) Type 3a and type 3b OFF cone bipolar cells provide for the alternative rod pathway in the mouse retina. J Comp Neurol 502:1123-1137. CrossRef Medline

Matsuoka RL, Jiang Z, Samuels IS, Nguyen-Ba-Charvet KT, Sun LO, Peachey NS, Chédotal A, Yau KW, Kolodkin AL (2012) Guidance-cue control of horizontal cell morphology, lamination, and synapse formation in the mammalian outer retina. J Neurosci 32:6859-6868. CrossRef Medline

Matthews G, Fuchs P (2010) The diverse roles of ribbon synapses in sensory neurotransmission. Nat Rev Neurosci 11:812-822. CrossRef Medline

McCall MA, Gregg RG (2008) Comparisons of structural and functional abnormalities in mouse b-wave mutants. J Physiol 586:4385-4392. CrossRef Medline

Meeks JP, Arnson HA, Holy TE (2010) Representation and transformation of sensory information in the mouse accessory olfactory system. Nat Neurosci 13:723-730. CrossRef Medline

Morgan JL, Dhingra A, Vardi N, Wong RO (2006) Axons and dendrites originate from neuroepithelial-like processes of retinal bipolar cells. Nat Neurosci 9:85-92. CrossRef Medline

Nishimura-Akiyoshi S, Niimi K, Nakashiba T, Itohara S (2007) Axonal netrin-Gs transneuronally determine lamina-specific subdendritic segments. Proc Natl Acad Sci U S A 104:14801-14806. CrossRef Medline

Pan F, Massey SC (2007) Rod and cone input to horizontal cells in the rabbit retina. J Comp Neurol 500:815-831. CrossRef Medline

Peachey NS, Ball SL (2003) Electrophysiological analysis of visual function in mutant mice. Doc Ophthalmol 107:13-36. CrossRef Medline

Peichl L, González-Soriano J (1993) Unexpected presence of neurofilaments in axon-bearing horizontal cells of the mammalian retina. J Neurosci 13:4091-4100. Medline

Peichl L, González-Soriano J (1994) Morphological types of horizontal cell in rodent retinae: a comparison of rat, mouse, gerbil, and guinea pig. Vis Neurosci 11:501-517. CrossRef Medline

Poch é RA, Kwan KM, Raven MA, Furuta Y, Reese BE, Behringer RR (2007) Lim1 is essential for the correct laminar positioning of retinal horizontal cells. J Neurosci 27:14099-14107. CrossRef Medline

Rao-Mirotznik R, Harkins AB, Buchsbaum G, Sterling P (1995) Mammalian rod terminal: architecture of a binary synapse. Neuron 14:561-569. CrossRef Medline

Raven MA, Oh EC, Swaroop A, Reese BE (2007) Afferent control of horizontal cell morphology revealed by genetic respecification of rods and cones. J Neurosci 27:3540-3547. CrossRef Medline

Reese BE, Raven MA, Stagg SB (2005) Afferents and homotypic neighbors regulate horizontal cell morphology, connectivity, and retinal coverage. J Neurosci 25:2167-2175. CrossRef Medline

Regus-Leidig H, Brandstatter JH (2012) Structure and function of a complex sensory synapse. Acta Physiol (Oxf) 204:479-486. CrossRef

Regus-Leidig H, Tom Dieck S, Specht D, Meyer L, Brandstätter JH (2009) Early steps in the assembly of photoreceptor ribbon synapses in the mouse retina: the involvement of precursor spheres. J Comp Neurol 512:814-824. CrossRef Medline
Rodieck RW (1991) The density recovery profile: a method for the analysis of points in the plane applicable to retinal studies. Vis Neurosci 6:95-111. CrossRef Medline

Sanes JR, Zipursky SL (2010) Design principles of insect and vertebrate visual systems. Neuron 66:15-36. CrossRef Medline

Shen K, Scheiffele P (2010) Genetics and cell biology of building specific synaptic connectivity. Annu Rev Neurosci 33:473-507. CrossRef Medline

Siddiqui TJ, Craig AM (2011) Synaptic organizing complexes. Curr Opin Neurobiol 21:132-143. CrossRef Medline

Soto F, Ma X, Cecil JL, Vo BQ, Culican SM, Kerschensteiner D (2012) Spontaneous activity promotes synapse formation in a cell-type-dependent manner in the developing retina. J Neurosci 32:5426-5439. CrossRef Medline

Su CY, Menuz K, Carlson JR (2009) Olfactory perception: receptors, cells, and circuits. Cell 139:45-59. CrossRef Medline

Tang T, Li L, Tang J, Li Y, Lin WY, Martin F, Grant D, Solloway M, Parker L, Ye W, Forrest W, Ghilardi N, Oravecz T, Platt KA, Rice DS, Hansen GM, Abuin A, Eberhart DE, Godowski P, Holt KH, et al. (2010) A mouse knockout library for secreted and transmembrane proteins. Nat Biotechnol 28:749-755. CrossRef Medline

Taniguchi H, He M, Wu P, Kim S, Paik R, Sugino K, Kvitsiani D, Fu Y, Lu J, Lin Y, Miyoshi G, Shima Y, Fishell G, Nelson SB, Huang ZJ (2011) A resource of Cre driver lines for genetic targeting of GABAergic neurons in cerebral cortex. Neuron 71:995-1013. CrossRef Medline

tom Dieck S, Specht D, Strenzke N, Hida Y, Krishnamoorthy V, Schmidt KF, Inoue E, Ishizaki H, Tanaka-Okamoto M, Miyoshi J, Hagiwara A, Brandstätter JH, Löwel S, Gollisch T, Ohtsuka T, Moser T (2012) Deletion of the presynaptic scaffold CAST reduces active zone size in rod photoreceptors and impairs visual processing. J Neurosci 32:12192-12203. CrossRef Medline

Tripodi M, Evers JF, Mauss A, Bate M, Landgraf M (2008) Structural homeostasis: compensatory adjustments of dendritic arbor geometry in response to variations of synaptic input. PLoS Biol 6:e260. CrossRef Medline

Vardi N (1998) Alpha subunit of Go localizes in the dendritic tips of ON bipolar cells. J Comp Neurol 395:43-52. CrossRef Medline

Wachtmeister L (1998) Oscillatory potentials in the retina: what do they reveal. Prog Retin Eye Res 17:485-521. CrossRef Medline

Wässle H (2004) Parallel processing in the mammalian retina. Nat Rev Neurosci 5:747-757. CrossRef Medline

Wässle H, Puller C, Müller F, Haverkamp S (2009) Cone contacts, mosaics, and territories of bipolar cells in the mouse retina. J Neurosci 29:106-117. CrossRef Medline

Whitney IE, Raven MA, Ciobanu DC, Poché RA, Ding Q, Elshatory Y, Gan L, Williams RW, Reese BE (2011) Genetic modulation of horizontal cell number in the mouse retina. Proc Natl Acad Sci U S A 108:9697-9702. CrossRef Medline

Williams ME, de Wit J, Ghosh A (2010) Molecular mechanisms of synaptic specificity in developing neural circuits. Neuron 68:9-18. CrossRef Medline

Wycisk KA, Budde B, Feil S, Skosyrski S, Buzzi F, Neidhardt J, Glaus E, Nürnberg P, Ruether K, Berger W (2006) Structural and functional abnormalities of retinal ribbon synapses due to Cacna2d4 mutation. Invest Ophthalmol Vis Sci 47:3523-3530. CrossRef Medline

Yamagata M, Weiner JA, Sanes JR (2002) Sidekicks: synaptic adhesion molecules that promote lamina-specific connectivity in the retina. Cell 110: 649-660. CrossRef Medline

Zhang W, Rajan I, Savelieva KV, Wang CY, Vogel P, Kelly M, Xu N, Hasson B, Jarman W, Lanthorn TH (2008) Netrin-G2 and netrin-G2 ligand are both required for normal auditory responsiveness. Genes Brain Behav 7:385-392. CrossRef Medline

Zhu X, Li A, Brown B, Weiss ER, Osawa S, Craft CM (2002) Mouse cone arrestin expression pattern: light induced translocation in cone photoreceptors. Mol Vis 8:462-471. Medline 